\title{
SOCIO-PHILOSOPHICAL ESSENCE OF THE FAMILY IN THE TRADITIONAL WAY OF LIFE OF THE UZBEK PEOPLE
}

\section{(C)Abdikarimova S., Khorezm Mamun Academy, Urgench, Uzbekistan, Xorazm@yumh.uz \\ СОЦИАЛЬНО-ФИЛОСОФСКАЯ СУЩНОСТЬ СЕМЬИ В ТРАДИЦИОННОМ УКЛАДЕ ЖИЗНИ УЗБЕКСКОГО ЭТНОСА}

(С)Абдикаримова С. С., Хорезмкая академия Мамуна, г Ургенч, Узбекистан, Хогаzm@уитh.uz

Abstract. In this article is discussed the concept of ethnic tradition, which is a respected tradition of the nation, became by firm phenomena in their everyday life, lifestyle and consciousness. The same time the idea of the family plays solving role in the protection of ethnic traditions such as care, contemplate, immorality and ethnic attribute households' traditions, their transformation from generation to generation and information in wits, lifestyle and heart of the people.

Аннотация. В данной статье рассматривается концепция этно-традиционализма, в которой уважаются традиции нации, ставшие устойчивым явлением в их повседневной жизни, образе жизни, менталитете и самосознании. В то же время идея семьи играет решающую роль в защите этно-традиционных верований, таких как забота, созерцание, бессмертие и этническая принадлежность семейных традиций, их трансформация из поколения в поколение и трансформация в умы, образ жизни и сердца людей.

Keywords: ethnic traditions, people, nation, culture, lifestyle, nationality, family, family traditions, humanism, education, heredity, inheritance.

Ключевые слова: этно-традиции, народ, нация, культура, образ жизни, национальность, семья, семейные традиции, гуманизм, воспитание, наследственность, наследство.

People are eternal with persistent enthusiasm of the nation the ethnos, who have such characteristics or who are not familiar with them, have been expelled from the history scene or assimilated by other ethnicities. For this reason, he has striven for a social-historical position for the sake of his future and has sought to strengthen the nation's traditions, to embrace the life of his descendants. The Uzbek people have such experience in their history [1].

Ethnic traditions are called that have become a stable vowel in their daily lives, lifestyle, mentality and subtlety. They constitute the core of the nation's ethnology. Doctor of Philosophy, Professor O. Nishonova writes that the Uzbek ethnonym consists of a long part and a superficial body. Without nutrition, the majority of the population cannot demonstrate themselves.

Family plays a decisive role in protecting ethnic traditions. It is inevitably a source of respect for the ethnocentric of family intimidation, contemplation, bravery and nationalism. It transmits them from generation to generation, transforming them into the minds, lifestyles and hearts of young people into a humanistic heritage. The family is not merely a union of roles but rather forms intercultural relations. This relationship gives birth through the tradition. According to M. Mid, ethnographical ethnocultural values of the tribes of the tribes of tribes are a normative influence on the cultural life, religion, and youth. K. K. Klakhon writes; Why Chinese Do not likes Milk and Milk Products? Why do Japanese volunteers go to the scientist on a voluntary basis? These Americans are from the point of view. Nobleman, why do some people come from fatherhood? 
Others think of the mother, and the third as one of them? Perhaps different peoples have different instincts, but God has ordained them various traditions, such as China. Is the weather different in Japan and the USA? But the good opinion is that 'because they have trained'. Ethnography is a collection of folklore. That is to say, the lesson is based on ethnocanistics, and the spiritual and inspirational geniuses in them are embodied in the minds of the youth. As the writer U. Korabayev writes, 'the people of the Uzbek family, as well as the people of our nation, are the rituals of living in a community, the struggle for being leader, the rituals (from childhood, the bridegroom), the funeral ceremonies of various burials, sacrificial ceremonies, such as polygamy, exogamy, monogamy, which became the basis of marriage and feasts, played a key role in the development of the primitive community' [2].

They have a crucial role in protecting and increasing the achievements of primitive people life. Additionally, he writes about family ethnic traditions, customs, and ceremonies: create family ceremonies and family marriages, develops and tests. Family ceremonies are a component of folk spirituality, important ethical character, an effective moral education. Characteristics such as morals and well-being which are characterized by the process of family worship are important in the formation of the youth culture. The young men educated in national traditions are different from others. A. Ashirov writes that some of the socially oriented aspects of family ethnocentrism are related to the ethnogenesis and ethnocentric processes dependent. Family is a unit of genealogical experiments aimed at understanding the universe, the life of the nation, its imaginations about the existence, and the universe. It is based on the experience of the family, the unity, the upbringing of children, and the burden of the future, because the People, who have little or no future, rely on historical and cultural experiences of the nation, and consider them as their sacred duty to the hearts of their descendants. Objects of the family of the Uzbek family can be influenced by different objects and subdivisions, goals and objectives, genesis and transformation, national and humanity, advocacy and conservatism, stability and dynamism. The members of the Uzbek family are primarily responsible for the preservation of historical and cultural celebrations and the socialization of young people [3].

The people aspire to preserve the cultural treasures of the nation, rituals, oral, art, books and souvenirs. This process cannot be small, it must be organized. If this task fails, the museum will be merely a packet, luggage, a warehouse for things. Historical and cultural life is adapted to the vibrant life, dynamics of change, interest and needs. Hence, this adaptation can sometimes lead to assimilation, forgetting adolescents. Some people, nations, and civilizations have stepped down from the historical scene. For this reason, the social responsibility of family members is primarily for the protection of the ethnos. The people are able to create the active sub-sect of socio-historical processes of the nation, make the studies purposeful, and socialize with intelligent, sociable, and intellectually advanced children [4].

Sh. M. Mirziyoev, President of the Republic of Uzbekistan, signed a decree on February 2, 2018, "On the Fundamental Support to Women's Empowerment and Institutional Strengthening", the Decree of the President of the Republic of Uzbekistan "On the Fundamental Principles on the Problems of Rich Cultural and Historical Heritage and Families, conducting practical and innate researches, strengthening the institution of the family based on them, and preparing young people for family life". The socialization of young people starts from the family, and the attitudes of the family institute shape their relationship to society, the environment, and the ongoing reforms. For example, if a family has the opportunity to learn books and learn, this is the case with children, and that parents do not require evidence of professionalism in their children. The active involvement of socialism in family and community life is a reflection of an active response to problems that are troubling them. Our great ancestor, Alisher Navoi, reflects on our ethnography, do 
not worry, you have poetized yourself. In another place, the thinker says: "Humans did not have a great long life, and they did not do much hard work. So, it is the duty of a relative to enjoy the family and the land. Through socializing, he demonstrates that he is a conscious being, an active subjunction, contributing to the further improvement of the family and society's life. From this point of view, the role and importance of family methodologies, which will help to socialize, serve to transform the individual into a social subject" [5].

\section{References:}

1. Nishonova, O. (2013). Esteticheskaya priroda uzbekskoi etnografii. Tashkentб Fan. (in Russian).

2. Seredina, M. (1988). Kul'tura i mir detstva. Izbrannye raboty. Moscow, (in Russian).

3. Klakhon, K. K. (1998). Zerkalo dlya muzhchiny. Vvedenie v antropologiyu. St. Petersburg, Evraziya. (in Russian).

4. Ashirov, A. (2006). Nekotorye filosofsko-eticheskie problemy semeinykh tseremonii. Filosofiya i pravo. (in Russian).

5. Navoi, A. (2006). Khikmatlar. Tashkent. (in Russian).

\section{Список литературы:}

1. Нишонова О. Эстетическая природа узбекской этнографии. Ташкент: Фан, 2013.

2. Середина М. Культура и мир детства. Избранные работы. М., 1988.

3. Клахон К. К. Зеркало для мужчины. Введение в антропологию. СПб: Евразия, 1998.

4. Аширов А. Некоторые философско-этические проблемы семейных церемоний // Философия и право, 2006.

5. Навои А. Хикматлар. Ташкент, 2006.

\section{Работа поступила}

в редакиию 14.09.2019 2.

\section{Принята к публикации}

19.09.2019 2.

\section{Ссылка для циитирования:}

Abdikarimova S. Socio-Philosophical Essence of the Family in the Traditional Way of Life of the Uzbek People // Бюллетень науки и практики. 2019. Т. 5. №10. С. 308-310. https://doi.org/10.33619/2414-2948/47/36

Cite as (APA):

Abdikarimova, S. (2019). Socio-Philosophical Essence of the Family in the Traditional Way of Life of the Uzbek People. Bulletin of Science and Practice, 5(10), 308-310. https://doi.org/10.33619/2414-2948/47/36 (in Russian). 